\title{
Leg Press
}

National Cancer Institute

\section{Source}

National Cancer Institute. Leg Press. NCI Thesaurus. Code C122033.

An exercise performed by using the legs to push a weighted bar or lever away from the body while seated or reclined. 